\title{
The Effects of Inflation on Commercial Banks
}

\section{G. J. Santoni}

EOPLE disagree about the effect of the recent decline in inflation on U.S. financial institutions. Some claim that the "sudden drop in inflation ... put the country's whole credit structure under great strains that are becoming increasingly apparent." One of the more important indicators of the "strain," according to this argument, is the increase in bank failures." Others argue that financial institutions have been the "beneficiaries of disinflation and falling interest rates," pointing out that commercial bank eamings increased as tha inflation rate fell."

This article discusses the effeet of inflation on commercial banks by analyzing the relationship between inflation and the maket value of bank capital.

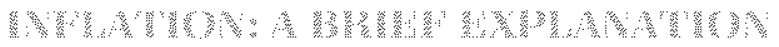

Inflation is an increase in the general price level, and is typically expressed as an annual percentage rate of change. For example, the GNP deflator tone index of the general price level] rose from 1.00 in 1982 to 1.038 in 1983 , then increased to 1.081 in 1984 . Inflation averaged 3.8 percent during $1982-83$ and about 4.1 percent during $1983-84$. The average amnual rate over the two-year interval was about 3.9 percent."

G. J. Santoni is a semor economist at the Federal Reserve Bank of St. Louis. Thomas A. Pollmann provided research assistance.

See Shaky Credił Structure (1985).

zibid.

See Corporate Eamings Uneven (1985).

4here are various methods of computing average annual rates of change. The method employed in this paper assumes continuous compounding. The rates are calculated by dividing the difference between the natural logarithms of the price level at the two points in time by the number of intervening years and multiplying by 100 .
Inflation depreciates the value of money. An in flation rate of 4.0 percent means that the dollar fatls in value at an annual rate of 4.0 percent in terms of the goods it will buy.

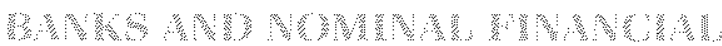

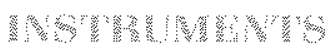

Inflation is important for banks because they typically deal in nominal financial instruments, that is, instruments denominated in fixed dollar amounts. For example, when a bank makes a loan, it accepts nominal financial instruments inotes, mortgages. commercial paper and other financial securitiest as evidence of the debtor's obligation to the bank. When a bank borrows, it issues nominal financial instruments to creditors (deposit liabilities, acceptances and debentures) as evidence of its obligation.

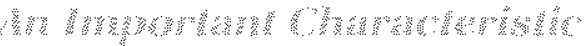

While nominal financial instruments differ from one another in many respects, they share one important characteristic: their payments are fixed in nominal value, that is, in terms of dollars. Nominal instruments make up the bulk of bank assets and liabilities. Furthermore, banks are typically net ereditors in nominal instruments because their nominal assets exceed their nominal liabilities see appendix 1 for a theoretical explanation $)^{3}$

\footnotetext{
sSee Alchian and Kessel (1977a) and Kessel (1956). Of course, banks have real assets and liabilities as well (land, buildings, office equipment, equities, etc.). These, however, make up a very small portion of bank portfolios and are irrelevant in assessing the effect of inflation on banks.
} 


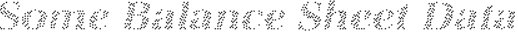

Table 1 uses data from the consolidated balance sheet of domestically chartered commercial banks to illustrate their net position in nominal instruments." Nominal assets are calculated by subtracting the values of bank premises, other real estate owned, the equities of other firms owned, and investment in subsidiaries from total assets. These items are subtracted because the market prices of real assels vary directly with the price level. Nominal liabilities are the sum of total deposits, subordinated notes and debentures. federal funds purchased, interest-bearing demand notes, mortgage indebtedness, all other liabilities for borrowed money and the value of preferred stock. Preferred stock, which is similar to a bond, is included as a nominal liability because it is an obligation of the bank to pay a fixed stream of dollars.

The table 1 data indicate that in the aggregate, the nominal assets of these banks exceed their nominal liabilities. The excess of nominal assets over nominal liabilities amounts to 66.3 percent of bank capital.?

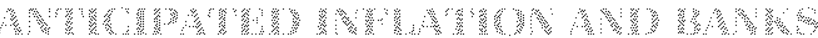

An increase in anticipated inflation raises the nominal interest rate. This increases the number of dollars that creditors or debtors who are transacting in nominal financial instruments expect to receive or pay when loans mature (see shaded insert t. If these expectations are realized, all nominal values will be higher at maturity. Table 2 shows this effect on the balance sheet of a hypothetical bank. The example assumes that all of the bank's borrowing and lending contracts were negotiated with the expectation that the rate of inflation over the next two years would be 5.0 percent. The bank's loan contracts have a two-yea life. its borrowing contracts mature at the end of each year and are renegotiated at the existing interest rate. Reserve requirements against all deposits are 10.0 percent.

For simplicity, the real interest rate is assumed to be zero so the nominal interest rate on bank loans is 5,0 percent." The interest rate on bank deposits is 4.5

\footnotetext{
${ }^{6}$ This calculation should be considered as illustrative only, since book values rather than market values are used.

${ }^{7}$ As above, capital excludes outstanding preterred stock.

${ }^{8}$ The assumption about the real rate has no qualitative effect on the results. See appendix 1.
}

\section{Table 1}

\section{Net Nominal Assets of All Commercial Banks (in billions of dollars)}

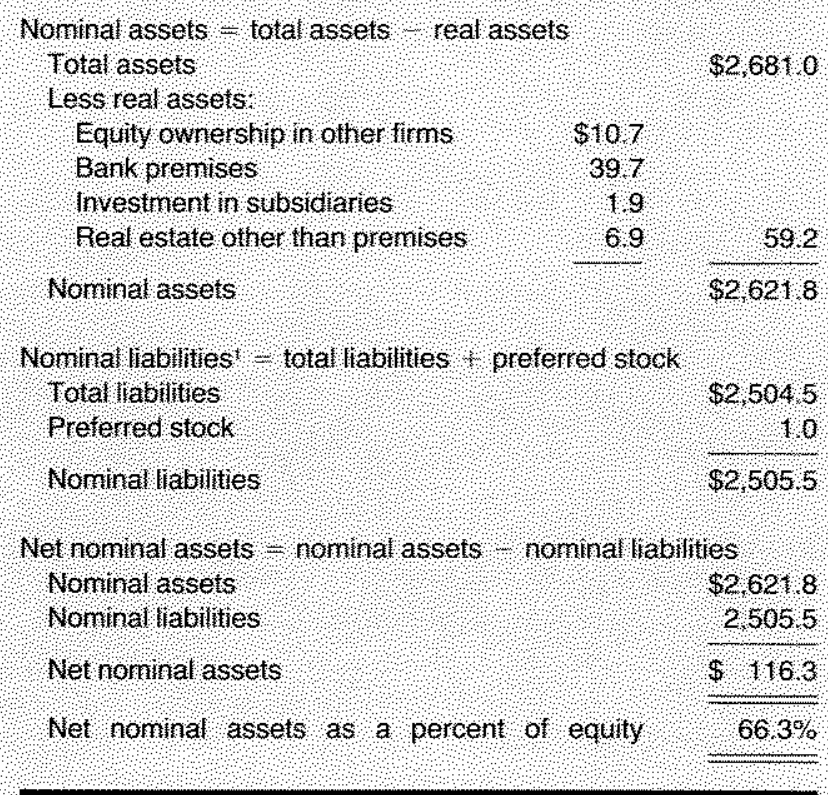

NOF Data are as of thind quanter 1985

Albank lablities are nommat

SOURCE Board of Govenors of the Federal hosene system

percent. The spread between the bank's borrowing and lending rates is necessary compensation for the requirement to hold non-interest-eaming reserves (see appendix 1). All assets and liabilities are valued at market prices so assets minus liabilities, or capital, represents the market value of the bank, $\$ 200$, in this example. The general level of prices is $1.0 \mathrm{in}$ panel $\mathrm{A}$.

Panel B shows the balance sheet of the bank at the end of the first year assuming that the anticipated intlation is realized and that nothing else has occurred to change the account balances. Accrued interest on deposit liabilities is $\$ 45$, while $\$ 50$ interest has accued on bank loans. A portion of the bank's interest earnings $(\$ 4.50)$ must be added to reserves to cover the increase in deposits. The nominal value of bank capital has increased to $\$ 210.00$, but its real value is unchanged $1 \$ 200.00$.

A similar result occurs in panel $\mathrm{C}$, which shows the balance sheet at the end of the second year. The anticipated inflation has no real effect on the bank's capital and, therefore, on the wealth of its stockholders. 


\section{Forecasting Inflation}

\section{Anticipated and Unanticipated inflation}

Many economic Iransactions require a commitment to exehange noney at some future time. Credit transactions are a good example of this. Since inflation reduces the future value of money, it pays people both potential borrowers and lenders) to try to forecast inlation over the relevant time period. This forecast is called antictpated inflation? As the name suggests, anticipated inflation is forward-looking it is the rate of change in the general price level that people think will oecur dining some specilic fatture time period.

of course, the accuracy of inflation forecasts depends on futuro events and circumstances that ate unknown when the forecast is made conse quently these forecasts generally will be "wrong;" Any difference between actual (or realized) intlation and anticipated inflation is called unanticipated inflation Unanficupated inflation is known only with hindsigh Because it is known only after the fact it plays no role in people's decisions it is important, however in assessing whether the dect sions produced profits or losses.

See Alchian and Alen $(977)$, 490 , hey note that thoughodd names are given to infation (creeping galloping runaway and hyper) a critcal distinction ls between unanticipated and anticl pated wiflation?

2 Economic theory suggests fhat, although wrong, the forecasts will not consistently over or underpredict that is forecasts will be unblased See Fisher 1954 , op 36-37 hisher $(1907), 0.213$ and Fame (1970) for discussions of business foresight and eff clent markets.

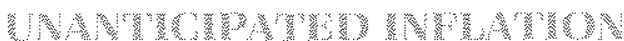 AN}

If the realized rate of inflation exceeds the anticipated rate, the price level has risen unexpectedly. The unexpected increase in the price level causes a proportional reduction in the exchange value of both nominal financial assets and liabilities in terms of real goods. Because banks are typically net creditors in nominal instruments, bank owners lose wealth when

\section{Anticipated Inflation and Interest} Rates

The nominal interest rates quoted in finaneial markets are formed in the process of contracting between borrowers and lenders. They indicate the number of dollars the bonower must pay to the ereditor in the future in exehange for a given num. ber of present dollars. If borrowers and lenders expect the value of the dollar to depreciate in terms of the goods it will buy over the life of the loan fi.e. if they anticipate inflation, the nominal interest rate speeified in the loan contraet will take aceount of this. The interest rate will be sufficiently high to compensate for the expected depreciation in the value of the dollar:

To illusirate, suppose the real interest rate is 3 percent and the anticipated rate of inflation over the coming year is 5 percent. People think that it Will take $\$ 105$ one vear fron now to purchase the geods that si oo will buy today. A loan of 51 , 000 for one year will require a payment of $\$ 1,081.50$ / $=$ $\$ 1,00000 \times 1.03 \times 1.051$ at maturity. This implies a nominal interest rate of 8.15 percent' The anticipated real value of this amount at maturity is 81,030 1 $=81081.501$ 05). Which is the stim of the principal $\$ 1,000$ and the real return $\$ 330$.

ssee fisher (1965), pp 1-100, who relates the nominal interest tale, 1 to the ex ante real terest rate,, and the antcipated rate of infation, $\pi$, as follows:

$$
1 \mathrm{t}+\mathrm{H}+\mathrm{n}(\mathrm{m})
$$

Eishers hypothesis fegarding the formation of the nominal inter est rate is an approximation to the stue' relationstip, 1 gnores risk premiuns and the effect of taxes on interest incone and assumes that the anticipated rate of intlation s held with certainty See Darby (1975) and Kochin (1981) The ex ante real rate is the premum in terns of real goods that oreditos exped 10 receve (and borrowers expect to pay expressed as a percentage of the principal of the loan See 7 sher (1954) and Santon and Stone (1981) tor discusstons of the real rate of interest

$8,15 \div 161,0015001,000001,1100$

there is unanticipated inflation (that is, when bank capital declines)."

Table 3 presents a numerical example of this effect. The assumptions in table 3 are the same as those in table 2 except that people are sumprised by a 10 per cent increase in the price level in the first year. The example assumes that the surprise is interpreted as a

${ }^{9}$ See Keynes (1923), pp. 18-19, and Alchian and Kessel (1977b). 


\section{Table 2}

\section{The Effect of an Anticipated Inflation of 5.0 Percent}

Panel A The gurnent balance sheet The price level is 1.0

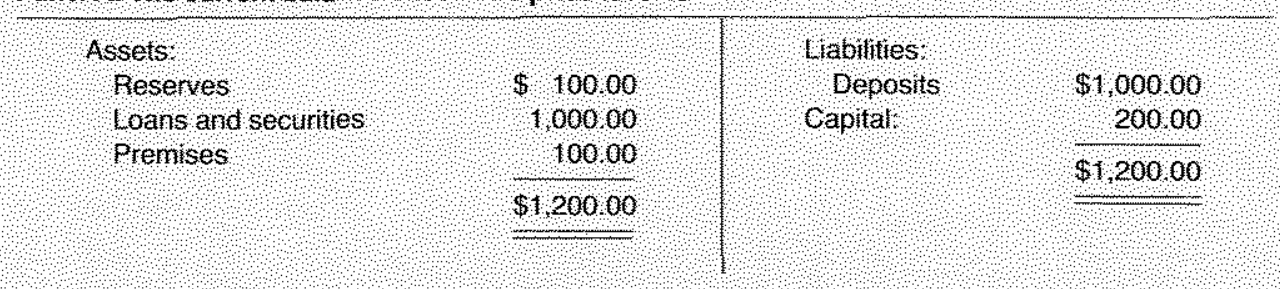

Panel B the balance sheet one year hence. The price level is 1.05 .

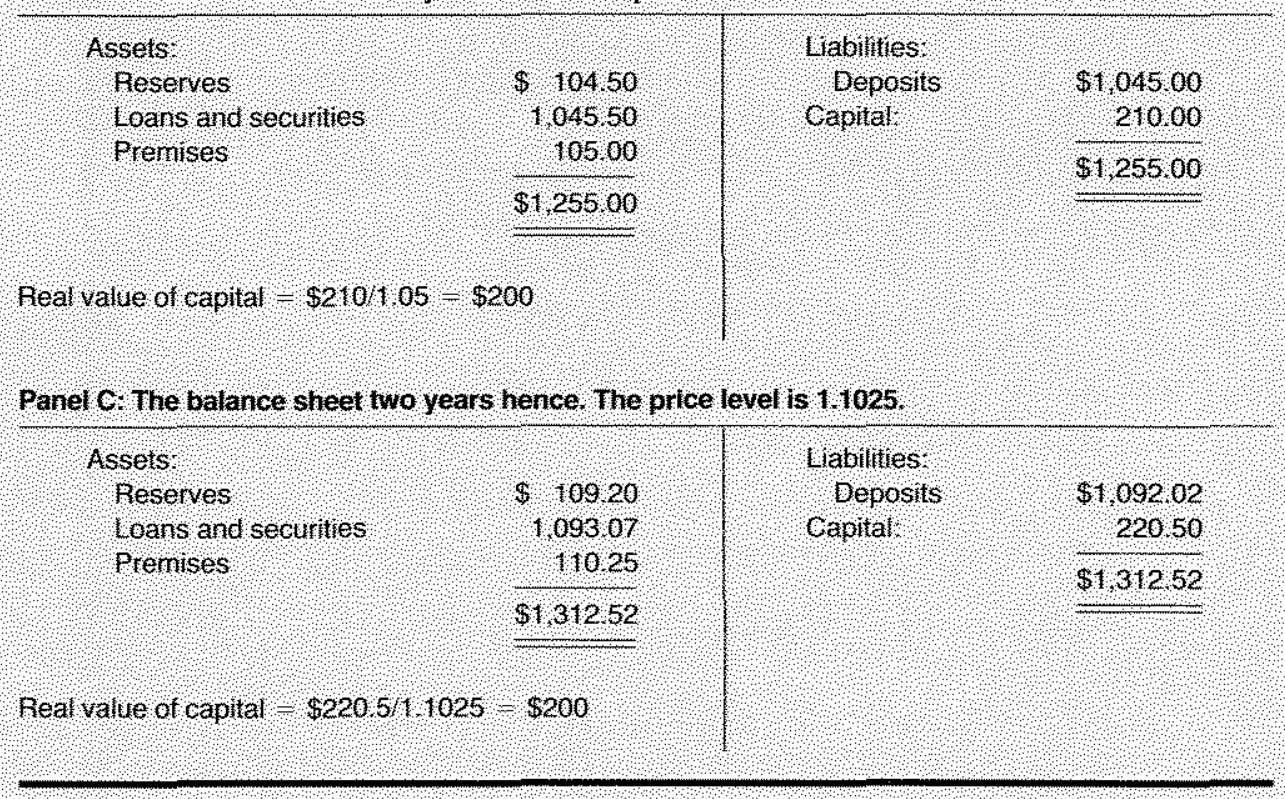

one-time only devation in the price level so that the inflation forecast for the second year remains at 5.0 percent.

Panel $B$ shows the effect of the unanticipated inflation. The bank's nominal assets and labilities are unafected by the inflationary surpriso. The increase in these dollar values is fxed by contract. fo contrast, the nominal value of the bank's real assets, the premises, increases by the realized rate of inflation, 10.0 percent. The nominal value of capital increases from $\$ 200$ to $\$ 215$. The value of the bank in terms of the real goods for which it can be exchanged, however, declines to \$195.45. The unanticipated inflation causes the real value of the bank to fall by $\$ 4.55 . "$

\footnotetext{
${ }^{19}$ An unanticipated decrease in the price level produces symmetrical results in that the real wealth of bank owners is increased
}

Panel C shows the bank's balance sheet at the end of the second year. The real value of the bank remains at $\$ 195.45$, indicating that the one-time inflationary surprise produces a permanent reduction in the teal value of the bank even though the rate of inflation in subsequent years returns to 5.0 pereent.

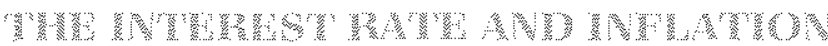

A bank's nominal financial assets and liabilities typi cally matume at diferent dates. At any given moment, the maluity dates of a bank's assets generally exfend beyond those of its habilities." In other words, an

\footnotetext{
"More precisety, the duration of the bank's receipt stream exceeds the duration of its payment stream. For discussions of duration, see Samuelson (1945), p. 19; Bierwag, Kaufman and Toevs (1983); Massel and Jacobson (1978); and Santoni (1984).
} 
Table 3

\section{The Effect of an Unanticipated Inflation}

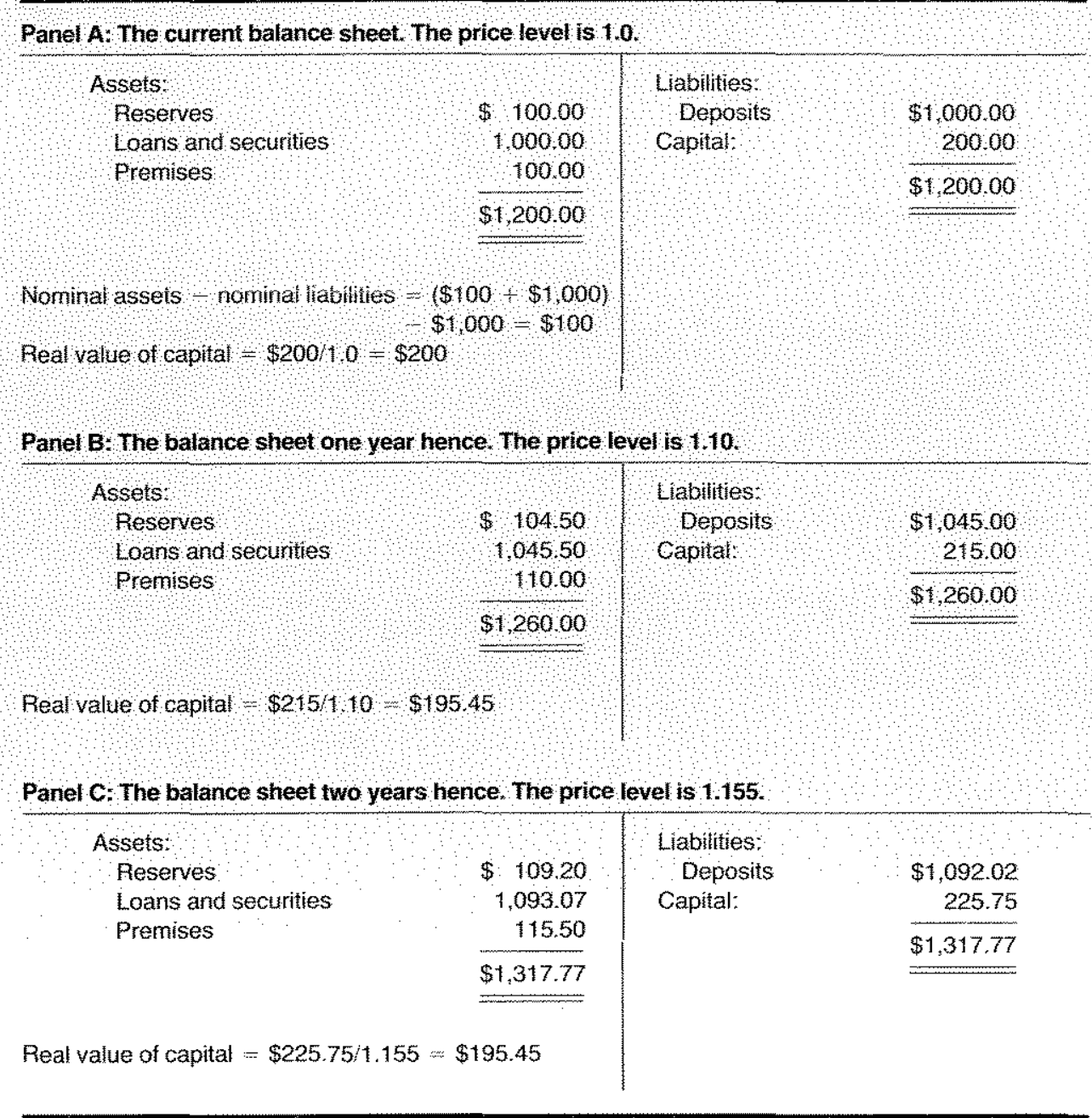

interest rate change alfects the payment stream obligated by the bank's liabilities before if affects the bank's ieceipl stream. Consequenty, an increase in the interest rate reduces the expected net stream of dollar receipts as the bank's ereditors renegotiate for the higher interest rate, while the interest rate aned by the bank on its existing loans is locked up. of course, the loans eventually mature and are renegotiated at the higher nominat rate, but the bank's capital is reduced nonetheless.

\section{Mron}

Table 4 illustrates the effect of a change in the nominal interest rate on bank capital. The example assumes the interest rate increases because anticipated inflation increases. The qualitative effect illusnated by the example, however, results from the change in the interest rate, regardless of what produced the change.

In this example, anticipated inflation at the time the bank initilly contracts with its ereditos and debtors is 5.0 percent. The bank's contracts with its credilors mature in one year, while its loans mature at the end of the second year and cannot be renegotiated before maturity.

As in the previous examples, the bank's loans and 


\section{Table 4}

\section{The Effect of a Change in Anticipated Inflation}

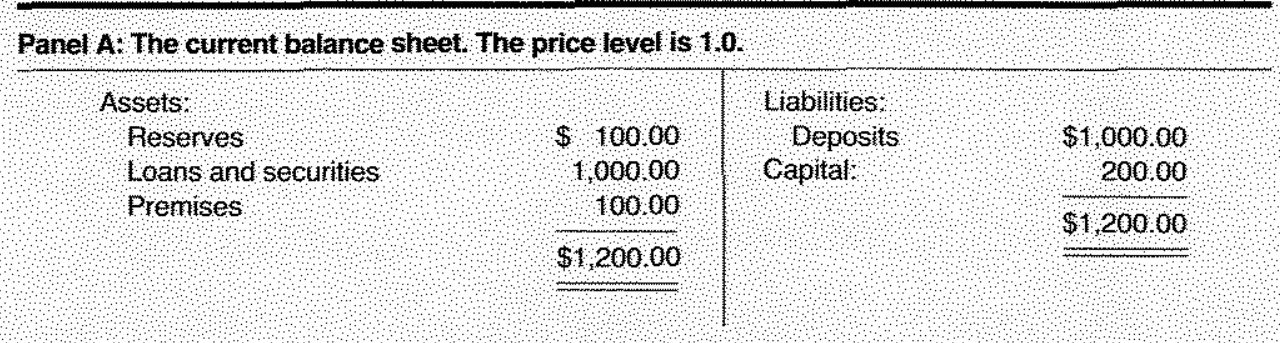

Panel B, The balance sheet one year hence, The price level is 105 .

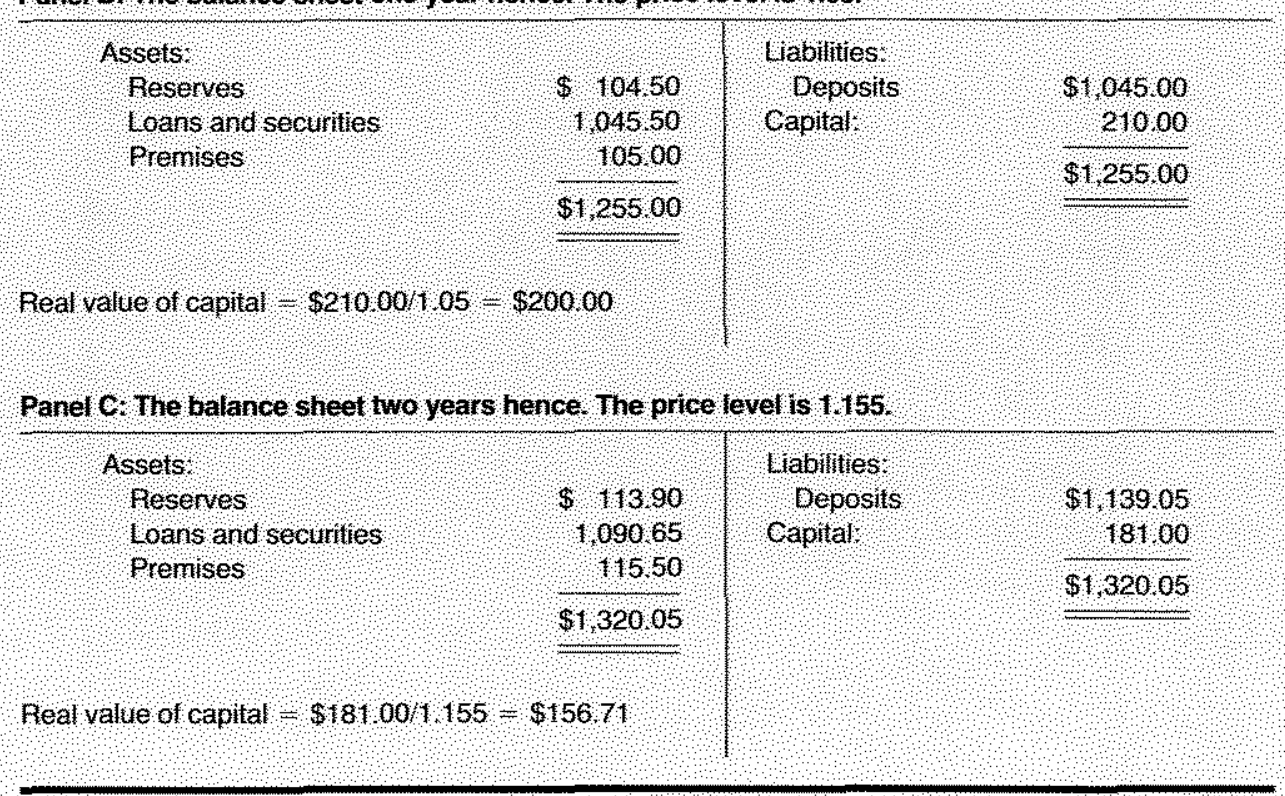

deposits are $\$ 1,000$. The lending rate is 5.0 percent, and the borrowing rate is 4.5 percent. Panel A shows the bank's initial balance sheet. Panel B shows the balance sheet at the end of the first year assuming that the realized rate of inflation during the fist year was 5.0 percent, the same as the anticipated rate.

Panel $C$ shows the balance sheet at the end of the second year assuming that the anticipated rate of inflation was mevised upwand to 10.0 percent at the beginning of the second year, just before the bank renegotiated its contraets with depositors. The example assumes that the realized rate of inflation during the second year matches the anticipated ate.

The increase in anticipated inflation causes the nominal interest rate to ise to 10.0 percent during the second year, white the interest rate on bank deposits increases to 9.0 percent. At the end of the second year, these deposits will amount $10 \$ 1,139.05(=\$ 1,045,00 \times$ 1.091. The bank, however, is prevented from maising the interest tate on its existing loans $1=\$ 1,000)$ by the tems of its contract. These loans continue to yield 5.0 percent in the second year accuing earnings of $\$ 50.00$ during the year. Of course, the bank can make new loans of $\$ 45.50$ at the beginming of the second year. These new loans, which result from the net interest earnings the bank obtained the first year, are made at the higher interest rate $(10.0$ percent and accue eamings of $\$ 4.55(\vec{w}=\$ 45.50 \times .10)$ at year $\mathrm{m}$.

Since bank deposits increased during the second year, some of the bank's interest earnings must be used to increase reserves. The increase in bank deposits amounts to $\$ 94.05 i=\$ 1,139.05-\$ 1,045.00)$, so 
reserves must increase to $\$ 113.90$ or by $\$ 9.401=\$ 94.05$ $x$.10). As a result, the bank's loan account at year-end is $\$ 1,090.65=\$ 1,000.00+\$ 50.00+\$ 45.50+\$ 4.55$ $\$ 9.40$. Bank premises increase in nominal value by the realized rate of inflation and amount to $\$ 115.501=$ $\$ 105.00 \times 1.10$ a a year-end. Note that both the nominat and real value of capital decline. The real vatue of capital falls by $\$ 43.29$ to $\$ 156.71 !=\$ 181.00 / 1.155)$.

As the lable 4 example shows, a change in the interest rate can have a farly substantial effect on the bank when the malurities of the bank's assets and habilities differ. In this particalar example, the real value of capital declined by about 22.0 perent when the interest rate doubled.

An increase in anticipated inflation affects banks in a way that is qualitatively the same as unanticipated inflation. This is because the upward revision in antic ipated tntation that occuss at the end of the first year was not forecast at the beginning of the year. If people had anticipated inflation of 5.0 percent the first year and 10.0 percent the second year, the late of interest on two-year loans would not have been 5.0 percent. Rather, it would have been higher to leflect the fact that anticipated inflation averages 7.2 percent across the two years. Lnanticipated inflation and changes in andicipated inflation have similar effects because both reflect a misguess about inflation.

To recap the main points so far, the previous discussion suggests that inflation alfects the real capital value of banks through two chamels. First, capital value falls when the actual rate of inflation exceds the anticipated rate, This is caled unanticipated inflation. Second, capital value falls when the anticipaled rate of inflation is revised upward, beatuse this causes nominal interest rates to rise unexpectedly. The reverse occurs if the actual wate of inflation falls short of the anticipated mate or if the anticipaled rate of inflation is revised downward.

\section{B.}

These implications can be examined by observing the effect of inflation on various indexes of the stock prices of publicly traded banks. Stock prices are used as a proxy for the capital value of banks because they represent the matket's assessment of the present value of the fulure net receipts banks are expected to generate.

The relationship between changes in the real stock prices of banks and the other variables is assumed to take the form shown in equation 1 :
(1) $\Delta \operatorname{Ln}\left(V / P_{1}=C+\alpha \Delta L_{\operatorname{Ln}}+\beta \Delta \operatorname{Ln}\left(i-\pi^{*}\right)_{1}+\gamma \pi_{1}^{\prime \prime}\right.$

$$
+\delta \pi^{*}+\varepsilon \Delta L \eta \pi^{*}
$$

where

$$
\begin{aligned}
V / P= & \text { the real price of bank stock, } \\
\mathrm{C}= & \text { a constant, } \\
y= & \text { real income, } \\
\left(\mathrm{i}-\pi^{*}\right)= & \text { the nominal interest rate less anticipated } \\
& \text { inflation, } \\
\pi^{*}= & \text { unanticipated inflation, which is the dif } \\
& \text { ference between realized inflation, } \pi \text {, and } \\
& \text { anticipated inflation, } \pi^{*} \cdot \pi^{*} \geq 0 .
\end{aligned}
$$

Equation 1 expresses real stock prices, real income, the interest rate residual and the change in anticim pated inflation in terms of annualized percentage changes. The unanticipated rate of inflation is the difference between two annualized percentage mates of change: the realized late of inflation and the anticipated rate. The estimates use quarterly data fom the first quarter of 1962 through the fourth quarter of 1984.

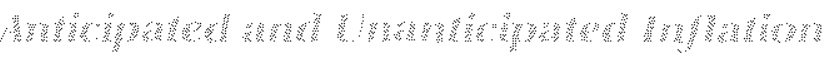

Measuring anticipated inflation is a problem. Since we only observe actual inflation, various analysts have used different methods to estimate anticipated inflation.":

This study estimates anticipated inflation one quarter ahead by employing a time-series forecast of inflation. This method genenates predictions of inflation solely on the bas is of its past behavior. The difference between the actual rate of intation and the rate forecast by the model is interpreted as the empirical counterpart of unanticipated inflation, $\pi$. Because the real price of bank stock is expected to be inversely related to unanticipated inflation, the coefficient of $\pi^{\text {" }}$ should be negative.

Anticipated inflation, $\pi^{*}$, and changes in the real price of bank stock are theoretcally unelated; consem quently, the coefficient of this variable should be zero. Changes in anticipated inflation change interest rates,

\footnotetext{
"See Hafer and Hein (1985).

3Roughly, the technique accounts for the past pattern of inflation by estimating a model that provides a description of the process that generated the observed series. Past observations of inflation are then used along with the information contained in the time-series model to forecast inflation one period ahead. For further discussion of time-series models and their properties, see Pindyck and Rubirfeld (1981), pp. 469-573, especially pp. 469-70 and 493-97. For further discussion of the model employed here, see appendix 2 .
} 
however, and these interest mate changes are expected to be inversely related to changes in stock prices. Estimates of the changes in anticipated inflation are obtained directly from the inflation forecasts."

\section{When}

Real income growth was included as an explanatory variable to control tor the effect of the business cycle on bark earnings. Business expansions increase the real quantity of bank loans, securities and deposits, which is thought to have a positive impact on the expected earnings stream. The empirical counterpart of real income used in the regressions is gross national product (GNP) divided by the GNP deflator. The expected sign of the coefficient of this term is positive.

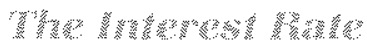

The prices of bank stocks are expected to be related to changes in the interest rate. The interest rate will vary with changes in the ex ante real interest rate, changes in income tax laws, changes in risk premiums and changes in anticipated inflation. Since the interest rate includes all of these factors, changes in it cannot be readily attributed to the effect of any one of them. The qualitative effect of a change in the interest rate on stock prices, however, is the same regardless of the source. The expected sign of the coefficient of interest rate changes is negative.

Since this paper focuses on the effect of inflation, the following estimates attempt to isolate the effect of a change in anticipated inflation. As mentioned above, an estimate of anticipated inflation, $\pi^{*}$, is produced by the time-series forecast of inflation. When this estmate is subtracted from the nominal interest ate, the resictual is an estimate of the nominal interest rate excluding anticipated inflation. Consequenty, changes in the estimate of anticipated inflation, $\Delta \pi^{*}$,

"Changes in the interest rate are expected to be positively related to changes in anticipated inflation. To check this, changes in the Aaa bond rate, $\Delta R$, and changes in the 3-month Treasury bill rate, $\Delta A S$, were regressed on the estimate of the change in inflation expectations. The resulis are presented below.

$$
\begin{aligned}
& \Delta R_{i}=.09+.13 \Delta \pi^{*} \\
& (1.93)(3.03)^{\star} \\
& \mathrm{DW}=1.65 \\
& \mathrm{~A}^{2}=.10 \\
& \begin{aligned}
\Delta \mathrm{RS}_{\mathrm{i}}= & .06+.36 \Delta \pi^{*} \\
& (.58)(3.71)^{2} \\
\mathrm{DW}= & 1.79 \\
\mathrm{~B}^{2}= & .14
\end{aligned}
\end{aligned}
$$

Athough both coefticients are less than one, they are both positive and significantly different from zero. The estimated coefficien of $\Delta \pi^{*}$ is larger in the equation for the short-term interest rate, which suggests that the inflation torecast used here is a beter estimate of short-run expectations. and changes in the difference between the nominal rate and the estimate of anticipated inflation, $\Delta\left(i-\pi^{*}\right)$, can be included separalely in the regression equation.: The expected sign of each of these tems is negative.

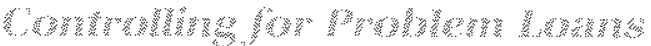

In addition to the above variables, the estimated equations include a dummy variable to control for the effect that recent latin American loan problems have had on bank stock prices. During the early bart of 1982 , it became apparent that certain batin American counfries would have difficulty honoring their obligations to IS. banks. In October and November 1982, the central bank of Brazil began borrowing heavily from the Exchange Stabilization f und of the U.S. Treasury; Mexico began drawing heavily on its swap arangement with the Federal Reserve System in April of the same year. News reports on the extent of the problem continued to suface for about three quarters. The period dummied begins in the first quarter of 1982 and extends through the third quarter of 1982, when it became evident that the U.S. government would take an active role in resolving the problem. "The expected sign of the dummy is negative.

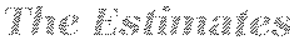

Table 5 presents the regression results. Fstimate 1 examines the effect of inflation on an index of the real share prices of banks located outside New York City. Estimate 2 does the same thing for New York City banks."

The signs of the estimated coefficients are as expected. The estimates indicate that unanticipated inflation and changes in the anticipated rate of intation are inversely related to changes in the real price of bank stock. As expected, the estimated coefficient of anticipated inflation is not signifcantly different from zero in a statistical sense.

\footnotetext{
15clually, the data entry is one plus the difference between the nominal rate and antcipated inflation. This is necessary because the difference is negative in some quaters during 1971, 1975 and 1976. See Brown and Santoni (1981) for a discussion of some problems associated with this method of separating the nominal rate into its various components.

TOn February 2, 1983 , the chairman of the Federal Reserve Board aditessed the House Committee on Banking. Finance and Urban Affaits regarding the problem and measures to deal with it. See Volcker (1983).

This was done because Standard and Poor's reports the data this way.
} 


\section{Table 5}

\section{Estimating the Effect of Inflation on the Price of Bank Shares, Sample Period: $1 / 1962-I V / 1985$}

Estimate 1.

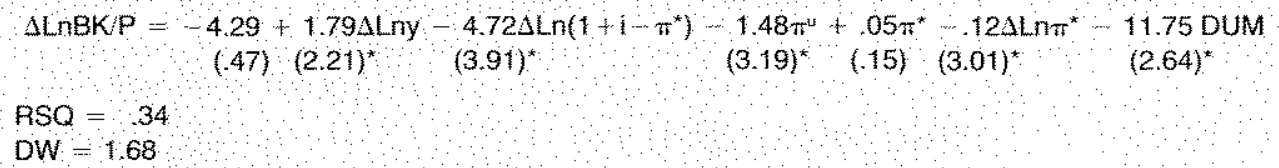

\section{Estimate 2:}

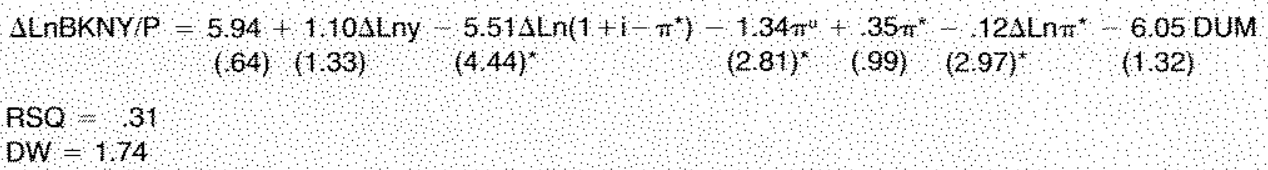

$\mathrm{BK} \mathrm{P}$ the Standard and Poors index of the real share prices of banks located outside New Yonk City

BKNYP = the Standard and Poors index of the real share prices of New York Gity banks

$y=$ Real Gross National Product

the corporate Aaa bond rate

mo unanticipated intlation

$\mathrm{t}^{*}$ enticpated intation

DUM $=1$ duning $1 / 982$ /1/1982 and zero othenwise

NOTE Absolute values of $t$-scores appear in parentheses 1 significantly different from zero at the 5 percent level

The coefficient of the dummy variable has the expected sign in both estimates but is not significant in estimate 2 . In the case of estimate 1 , the coefficient is significant and its point estimate is faily lange, stggesting that the growth in real stock prices was about 12 percent lower, on average, during the first three quarters of 1982, other things the same. This may be somewhat misleading since the confidence interval for this coefficient ranges from -2.9 to -20.7 .

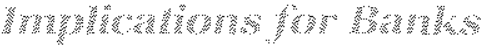

The average forecast of inflation $\left(\pi^{*}\right)$ genemated by the time-series model during 1984 was about 4.0 percent. This fell to about 3.5 percent during 1985 , resulting in a 13.5 percent drop in anticipated intlation $\left(\Delta L n \pi^{*}\right)$. The table 5 estimates suggest that this raised the real stock prices of the banks in the sample by about 1.6 percent $t=-13.5 \times-.12 t$. In addition, the dectine in the actual rate of inflation exceded the decline in anticipated inflation. As a result, unanticipated inflation averaged about -85 percent in 1985 . raising the real stock prices of banks by an additional 1.2 percent $(=-.85 \times-1.41$. In sum, the real stock prices of banks increased by about 3.0 percent, ceteris paribus, as a consequence of the fall in anticipated inflation in 1985 and because the actual mate of inflation in 1985 was even lower than anticipated.

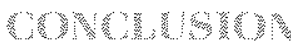

This paper examines the effect that inflation has on the share prices of commercial banks. The results indicate that the real share prices of banks are in versely related to both unanticipated inflation - that is, deviations in the realized rate of inflation from its anticipated rate - and enanges in anticipated inflation. Contrary to some claims, this evidence indicates that bank shareholders have benefited from the recent decline in the rate of inflation and that any mexpected resurgence of inflation would be hament.

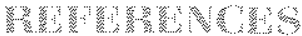

Alchian, Armen A., and William R. Allen, Exchange and Production: Competition, Coordination and Control, 2nd ed. (Wadsworth Publishing Company. Inc., 1977), pp. 490-94. 
Alchian, Armen A, and Reuben A. Kesset. "Effects of Inflation," Economic Forces at Work (Liberty Press, 1977a), pp. 363-96.

and

"Redistribution of Wealth Through fniflation," Economic Forces at Work (Liberty Press, 1977b), pp. 397$4+2$.

Bierwag, G. O., George G. Kautman and Alden Toevs. "Duration: Its Development and Use in Bond Portlolio Maragement," Firtart cial Analysts Journal (July/August 1983), pp. 15-35.

Brown, W. W. and G. J. Santoni. "Unreal Estimates of the Real Rate of Interest," this Review (Jantary 1981), pp. 18-26.

"Corporate Eamings Unever," New York Times, November 4, 1985

Darby, Michael R. "The Financial and Tax Effects of Monetary Policy on Interest Aates," Economic inquiry (June 1975), pp. 26676 .

Fama, Eugene F. "Efficient Capital Markets: A Review of Theory and Empirical Work," Joumal of Finance, Papers and Proceedings (May 1970), pp. $383-417$.

Fisher, Irving. Appreciation and Interest (Augustus M. Kelley, 1965), pp. $1-100$.

The Theory of Interest (Kelley and Miliman, 1954).

The Rate of Interest (The Macmillan Company, 1907).

Hater, R. W., and Scott E. Hein. "On the Accuracy of Time-Series, Interest Rate, and Survey Forecasts of Intlation," The Journal of Business (October 1985), pp. 377-98.
Kessel, Reuben A. "Inflation-Caused Wealth Redistribution: A Test of a Hypothesis," American Economic Review (March 1956), pp. $128-41$.

Keynes, J. M. A Tract on Monetary Reform (Macmillan and Company, 1923).

Kochin, Levis. "The Term Structure of Interest Rates and Uncertain inflation" (University of Washington, 1981 ; processed)

Maisel, Sherman J., and Robert Jacobson. "Interest Rate Changes and Commercia Bank Revenues and Costs," Joumal of Financial and Quantitative Analysis (November 1978), pp. 687-700.

Pindyck, Robert $\mathrm{S}$., and Daniel L. Rubinfeld. Econometric Models and Economic Forecasts, 2nd ed. (McGraw-Hill Book Company, 1981), pp. $469-573$.

Samuelson, Paul A. "The Effect of interest Rate ncreases on the Banking System," American Economic Review (March 1945), pp. $16-27$.

Santoni, G. J. "Interest Rate Risk and the Stock Prices of Financial Institutions," this Review (August September 1984), pp. 12-20.

, and Courtenay C. Stone. "Navigating Through the in" terest Rate Morass: Some Basic Principles," this Review (March 1981), pp. $11-18$.

"The Shaky Credit Siructure." Washington Post, November 4, 1985.

volcker, Paul A. Statement Before the Committee on Banking, Finance and Urban Affairs, House of Representatives, February 2 . 1983. 


\section{APPENDIX 1 \\ Some Banking Arithmetic}

In large part, a bank's expected stream of net revenue is generated by its holdings of nominal assets and liabilities. These are its loans, $L$, which earn the maket interest rate, $i_{m}$, and its deposits, $D$, on which interest, $i_{10}$ is paid. In addition, owners have invested capital, I, of which a fraction, $\alpha$, must be held as non-interestearning reseves against deposits, and the remaining fraction, $(1-\alpha)$, is held in either nominal or real assets that are expected to yield the market rate, $i_{m}$. The following assumes that this remainder is held entrely in net real assets. The expected stream of net revenue, $\mathrm{R}$, is given in equation 1 :

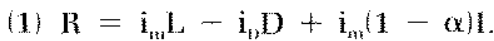

If the required reserve ratio is $p$, required reserves are $\rho D=\alpha$. The quantity of loans and deposits the bank can generate are $L=D=\alpha L / p$. In equilibrium, the expected revenue stream of the bank nust equal the alternative stream of eamings that could be obtained by investing the capital at the market interest fate. This is shown in equation 2 :

(2) $R=i_{m} L-i_{1}, 0+i_{m}(1-\alpha) l=i_{m} \alpha I+i_{m}(1-\alpha) I$

The capitat value of the bank, $K$, is shown in equation 3 :

(3) $\mathrm{K}=\frac{\mathrm{R}}{\dot{\mathrm{i}}_{\mathrm{m}}}=\alpha \mathrm{I}+(1-\alpha)=1$.
Equation 3 expresses the capital value of the bank as the present value of the stream of expected revenue. In equilibrium, $\mathrm{K}=\mathrm{I}$. If $\mathrm{K}$ were greater than $\mathrm{I}$, resources would be attracted to banking since the capital value of forming a bank would oxceed the opportunity cost. If $\mathrm{K}$ were less than $\mathrm{I}$, resources would leave the indusIIy.

\section{The Equilibrium Interest Rate on Bank Deposits}

Substituting $\rho \mathrm{D}$ for $\alpha \mathrm{I}$ in equation 2 and noting that $\mathrm{D}=\mathrm{L}$, the equilibrium interest rate on bank deposits is given in equation 4 :

(4) $\dot{i}_{4}=(1-\rho) i_{1+}$

\section{Banks as Net Creditors in Nominal Assets}

Net nominal assets, NNA, are nominal assets minus nominal liabilites. The bank's nominal assels are the sum of its loans and reserves, while the bank's deposits are its nominal liabilities. Assuming equilibrim, these are given in equation 5 :

(5) $\mathrm{NNA}=\mathbf{L}+\boldsymbol{L} \mathrm{D}-\mathrm{D}=\rho \mathrm{D}$.

Under these assumptions, the bank is a net creditor in nominal assets to the extent of its reserve holdings.

\section{APPENDIX 2}

\section{A Time-Series Forecast of Inflation}

While the initial observation for the regressions reported in the text is fist quarter 1962 , the data period used to develop the forecast of inflation fas moasured by the GNP deflator extends back to first quarer 1948. A backward extension is necessary to get the forecasting model started.

Since the period covered is quite long, a rough check of the data was made to detemine if the process that generated the time series changed materially over the period 1/1948-1V/1985. To do so, at model was fist estimated for $1 / 1948-1 / 1965$ and these results were compared with the results obtained from estimates for $1 / 1966^{-T} / 1985$. The GNP deflator appeas to be a second-order homogeneous process that can be modeled as ARIMA $10,2,11$. The estimated models for the two periods are reported below. Calculated $t$ stalistics appear in parentheses, and $B$ is a backward shifi operator, i.t., (1-B) $X_{1}=X_{1}-X_{1, q}$. 


\section{I/1948-IV/1965}

$\Delta^{2} \mathrm{LnP}_{1}=-.107+(1-.49 \mathrm{~B}) \mathrm{e}_{1}$ $(.58) \quad(4.73)$

Chi-square $(2,24\}=16.07$

\section{I/1966-IV/1985}

$\Delta^{n} \operatorname{Ln} P_{8}=.003+(1-.48 B) e_{1}$ (.03) $\quad(4.70)$

Chi-square $(2,24)=26.63$
A model was then estimated for the period $1 / 1948$-IV/ 1961 , and a forecast of inflation for $1 / 1962$ was made. The difference between the realized inflation rate for $\mathrm{l}$ 1962 and this forecast is interpreted as the empirical counterpart of $\pi^{13}$.

The forecast for the next quarter, $\mathrm{H} / 1962$, is generated by adding the realized inflation rate for $1 / 1962$ to the data and re-estimating the model through $1 / 1962$ and proceeding as above. The process was repeated for each quarter through IV/1985. 